\title{
Production of Microbiological Peptone from Hydrolysis of Slaughterhouse Offal Using Bacterial Protease
}

\author{
Medhanit Teshome*, Eleni Belay \\ School of Graduate Studies, Microbial, Cellular, and Molecular Biology Department, Addis Ababa University, Addis Ababa, Ethiopia \\ Email address: \\ medanit3@gmail.com (M. Teshome), elenibelay559@gmail.com (E. Belay) \\ ${ }^{*}$ Corresponding author \\ To cite this article: \\ Medhanit Teshome, Eleni Belay. Production of Microbiological Peptone from Hydrolysis of Slaughterhouse Offal Using Bacterial Protease. \\ International Journal of Microbiology and Biotechnology. Vol. 6, No. 2, 2021, pp. 45-52. doi: 10.11648/j.ijmb.20210602.13
}

Received: February 17, 2021; Accepted: March 29, 2021; Published: April 20, 2021

\begin{abstract}
Proteases are the most important class of industrial enzymes accounting for $60 \%$ of the global industrial enzyme market. Microorganisms are the major source of these enzymes. Production of hyrolysates from different protein sources is among the different application of proteases. Protein hydrolysates have a variety of food and non-food applications. Although different proteases are available in the market, there is always a need for the development of new enzymes from bacterial sources. This is especially important in countries like Ethiopia where there are no local enzyme producers. The aim of this study was, therefore, to isolate new protease producing bacterial isolates to be used for the hydrolysis of slaughterhouse offal, optimize enzyme production and hydrolysis conditions, and test hydrolysates as a microbiological growth media. Based on screening data on solid and liquid media, one bacterial isolate designated as $a a u_{5}$ was selected for further study. The isolate grew under solid-state fermentation (SSF) and produced up to 5,773 U/g of enzyme. Enzyme production was optimal when the solid to moisture ratio was $1: 2\left(66.7 \%\right.$ moisture content) and in the presence of organic nitrogen sources. Protease $a a u_{5}$ was optimally active at $\mathrm{pH} 7.5$ and temperature of $55^{\circ} \mathrm{C}$. After one hour incubation, the enzyme retained up to $66 \%$ and $41 \%$ of its original activity at $50^{\circ} \mathrm{C}$ and $55^{\circ} \mathrm{C}$, respectively. Protease $a a u_{5}$ was used for the hydrolysis of slaughter house offal (lung and bone) and soybean protein. The hydrolysate (peptone) was then tested as a microbiological media for the growth of different bacterial species. Compared to commercial peptone, hydrolysate obtained from lung (LPA) and bone extracted protein (BPA) supported better growth of the test organisms. So, by using waste and by products of slaughter houses, beneficial hydrolysate like peptone can be produced through enzymatic hydrolysis.
\end{abstract}

Keywords: Protease, Offal, Hydrolysis, Peptone

\section{Introduction}

Proteases are the most important class of commercial enzymes accounting for $60 \%$ of the global industrial enzyme market [1]. They find huge application in detergent, food, pharmaceutical, silk and leather industries.

Although all organisms produce proteases, from a commercial perspective microorganisms are the most preferred sources of these enzymes. This is because microorganisms have fast growth rate, require limited space for their cultivation and the ease at which their enzymes can be genetically manipulated to generate new enzyme variants for specific applications [2].

Protease production by microorganisms is affected by different parameters, such as growth temperature, quantity of inoculum, medium $\mathrm{pH}$, and type and composition of medium [3]. Once produced the activities of microbial protease can also be influenced by temperature and $\mathrm{pH}$ of the reaction medium. Thus based on the optimum reaction proteases are classified as acid, neutral or alkaline proteases [4].

One important application for microbial proteases is in the hydrolysis of proteins from different wastes, such as offal from slaughterhouses, feather from poultry processing industries and fish processing wastes [5]. Protein rich wastes released by slaughterhouses include meat attached to bone and animal viscera. The protein in these wastes can be enzymatically hydrolyzed in to peptides or amino acids and can be used for different applications. Some of the applications include use as food or feed supplements, leather tanning supplements, microbiological media and cosmetics 
$[6,7]$.

Currently the non-edible part of the cattle like, lung, trachea, kidney, brains, spleen, intestine, bone and other Slaughterhouse offal are mainly used for wild and domestic animals feed [8]. Considering the high protein content of these wastes, such practices are wasteful, especially for developing countries like, Ethiopia where the hydrolysate could find huge application in different sectors of the economy. For example in Ethiopia, the only known use for cattle lung is as a feed to cats. But in the majority of cases it is disposed as waste at the slaughterhouse. Similarly meat attached to bones and the intestine parts of cattle is also discarded to the garbage. This in addition to losing valuable resource, it potentially causes environmental pollution. Development of methods for the enzymatic hydrolysis of such offal is expected to have significant economic returns and that requires development of appropriate enzymes for the hydrolysis and optimization of the reaction conditions.

The aim of this study was, therefore, to isolate a new protease producing bacteria, characterize the enzyme, optimize reaction conditions for the hydrolysis of slaughterhouse offal and test the hydrolysates as a microbiological media.

\section{Materials and Methods}

\subsection{Isolation and Screening of Protease Producing Bacteria}

Soil samples were collected from different area of Addis Ababa university plant gardens and it was dried by air. To isolate bacterial isolates 1 gram of soil was suspended in $9 \mathrm{ml}$ of sterile distilled water and serially diluted in the range of $10^{-2}$ to $10^{-6}$. Then $0.1 \mathrm{ml}$ aliquot from each dilution was spread on skim milk agar plates containing $(\mathrm{g} / \mathrm{l})$ : skim milk powder, 10; peptone, 3; yeast extract, 3; $\mathrm{NaCl}, 5$; $\mathrm{MgSO}_{4} .7 \mathrm{H}_{2} \mathrm{O}, 0.2 ; \mathrm{CaCl}_{2}, 0.1$; and $\mathrm{K}_{2} \mathrm{HPO}_{4}, 0.2$, finally the $\mathrm{pH}$ was adjusted by $0.1 \%$ of $\mathrm{KH}_{2} \mathrm{PO}_{4}$ at $\mathrm{pH}$. After $48 \mathrm{hr}$ incubation at $37^{\circ} \mathrm{C}$, isolates that form clear hallo zone were considered protease positive. All positive isolates were purified through repeatedly streaking on agar plates. The pure isolates were preserved at $4^{\circ} \mathrm{C}$ for further study.

\subsection{Characterization of Selected Isolate}

The identification of bacteria was carried out by microscopic, morphological and biochemical studies. The biochemical tests were Gram staining and catalase activity. Culture characterization on agar plate like colony morphology was also done. In addition, starch and gelatin hydrolysis were tested.

\section{Enzyme Production}

\subsection{Submerged Fermentation}

Sterile skim milk broth $(25 \mathrm{ml})$ in a $250 \mathrm{ml}$ conical flask was inoculated with a loop full of the culture from fresh slants and incubated at $30^{\circ} \mathrm{C}$ on a rotary shaker at $150 \mathrm{rpm}$. After $48 \mathrm{hr}$ of incubation, $1 \mathrm{ml}$ of the culture was transferred to $1.5 \mathrm{ml}$ sterilized eppendorf tubes and centrifuged at 10,000 rpm for $5 \mathrm{~min}$. The cell free culture supernatant was used as crude enzyme preparation.

\subsection{Solid State Fermentation}

Solid substrate ( $10 \mathrm{~g}$ wheat bran) was transferred to a 250 $\mathrm{ml}$ conical flask; $13 \mathrm{ml}$ of salt solution with the composition of $\mathrm{NaCl}, 0.5 ; \mathrm{MgSO}_{4} .7 \mathrm{H}_{2} \mathrm{O}, 0.02 ; \mathrm{CaCl}_{2}, 0.01$; and $\mathrm{K}_{2} \mathrm{HPO}_{4}$, 0.02 , was added and autoclaved at $121^{\circ} \mathrm{C}$ for $30 \mathrm{~min}$. Each flask was inoculated with $2 \mathrm{ml}$ of the selected bacterial broth culture grown at $37^{\circ} \mathrm{C}$ for $48 \mathrm{hr}$. At the end of fermentation period, the enzyme was extracted by adding $100 \mathrm{ml}$ of distilled water followed by filtration through a muslin cloth.

\subsection{Protease Activity Assay}

Proteolytic activity was measured using casein as the substrate. To $450 \mu 1$ of $1 \%(\mathrm{w} / \mathrm{v})$ of casein in $50 \mathrm{mM}$ phosphate buffer, pH 7 was mixed with $50 \mu 1$ crude enzyme extract and incubated for $20 \mathrm{~min}$ in a water bath at $50^{\circ} \mathrm{C}$. The reaction was stopped by adding $450 \mu \mathrm{l}$ of $10 \%(\mathrm{w} / \mathrm{v})$ trichloroacetic acid (TCA) and was kept at room temperature for $10 \mathrm{~min}$. After centrifugation at 10,000 rpm for $5 \mathrm{~min}, 150$ $\mu \mathrm{l}$ supernatant was mixed with $750 \mu \mathrm{l}$ of $0.5 \mathrm{M} \mathrm{Na}_{2} \mathrm{CO}_{3}$ and $150 \mu 1$ of $1 \mathrm{~N}$ Follin Ciocalteus phenol reagent. The mixture was incubated in the dark for $30 \mathrm{~min}$ and absorbance was measured at $660 \mathrm{~nm}$ against a reagent blank. One unit of protease activity was defined as the amount of enzyme that resulted in the release of $1 \mu \mathrm{g}$ of amino acid equivalent to tyrosine per min.

\section{Characterization and Optimization of Reaction Conditions}

\subsection{Effect of pH on Enzyme Activity}

The effect of $\mathrm{pH}$ on activity of the enzyme was assayed in the $\mathrm{pH}$ range of $6.0-10.5$. The buffers used include phosphate $(\mathrm{pH} 6.0-8.0)$, Tris $\mathrm{HCl}(\mathrm{pH} 7.5-9.0)$, and glycine $\mathrm{NaOH}$ buffer ( $\mathrm{pH} 8.5-10.5)$.

\subsection{Effect of Temperature on Enzyme Activity}

The effect of temperature on enzyme activity was determined by performing the standard assay procedure at $\mathrm{pH} 7$ within a temperature range from $40^{\circ} \mathrm{C}$ to $65^{\circ} \mathrm{C}$ in a $5^{\circ} \mathrm{C}$ interval.

\subsection{Temperature Stability}

Thermo stability of enzyme was measured by incubating the protease alone in different eppendorf tube for different incubation time of $0,10,20,30,40,50$ and $60 \mathrm{~min}$ in a water bath at 50 and $55^{\circ} \mathrm{C}$. Then each of the incubated enzymes was assayed in the standard assay procedure at $50^{\circ} \mathrm{C}$. Finally the residual activity of protease enzyme was calculated as follow. 
Relative residual activity $(\mathrm{RRA})=\frac{\text { individual residual activity }}{\text { residual activity at time of } 0} \times$
$100 \%$

\section{Optimization of Culture Conditions for Enzyme Production}

The protease activity was determined by varying the $\mathrm{pH}$, temperature and fermentation period to optimize the reaction condition in order to scale up the target product.

\subsection{Time Course of Enzyme Production}

The culture medium was incubated for varying periods of time, 24, 48, 72, 96 and $120 \mathrm{hr}$ to find the optimum time required for maximum enzyme production by SSF media at $37^{\circ} \mathrm{C}$. At the end of the incubation time, the enzyme was harvested and activities were determined by standard enzyme assay procedure.

\subsection{Effect of Moisture Level}

Optimum moisture content required for the growth of bacteria and for protease production was determined by growing the organism at $37^{\circ} \mathrm{C}$ in the SSF media at a moisture level $(\mathrm{v} / \mathrm{w})$ of $33.3 \%, 50 \%, 60 \%, 66.7 \%$, and $75 \%$. The enzyme was harvested after $72 \mathrm{hr}$ and activity determined.

\subsection{Effect of Nitrogen Sources on Protease Production}

The effect of nitrogen sources for protease production was determined by organic and inorganic nitrogen source. This includes peptone, ammonium nitrate, yeast extract, casein and sodium nitrate. Each source was used at a concentration of $0.5 \%(\mathrm{w} / \mathrm{v})$ to replace nitrogen sources. Protease yield was determined after $72 \mathrm{hr}$ of incubation at $37^{\circ} \mathrm{C}$ in a SSF with the moisture content of $66.7 \%$.

\section{Collection and Preparation of Protein}

\subsection{Offal Collection (Animal Source)}

Samples of slaughterhouse offal (lung and raw meaty bone waste) was collected from the local retail butcher shop in sterilized container and transported to the laboratory. The lung was chopped and the meat on the bone was detached by using $\mathrm{NaOH}$ to dissolve proteins on the meat. Then the dissolved protein was precipitated by $\mathrm{HCl}$ [9].

\subsection{Soya Bean Protein Isolation}

Isolation of soya protein was carried out following the methods of the previous study [10]. A $10 \%(\mathrm{w} / \mathrm{v})$ of defatted soya flour was dissolved in distilled water and $\mathrm{pH}$ adjusted between $\mathrm{pH} 10-11$ using $1 \mathrm{~N} \mathrm{NaOH}$. After removing the insoluble fraction, the solution was precipitated by adjusting the $\mathrm{pH}$ in the range of 5 and 6 using $1 \mathrm{~N} \mathrm{HCl}$. The protein precipitate was recovered, dried in oven over night at $40^{\circ} \mathrm{C}$, and pulverized to a powder passing through a $250 \mu \mathrm{m}$ sieve.

\subsection{Deffatting Process}

1) Soya flour defatting

Soya flour from plant source was defatted by using hexane. The flour was soaked for $2 \mathrm{hr}$ and for this time solvent to flour ratio was 1:3. Then the defatted portion was separated through filtration and it was dried by atmospheric temperature (air- dried overnight).

2) offal defatting

First lung of the cattle was chopped by knife and soaked in hexane for $2 \mathrm{hr}$. the lung defatting process was repeated depending on the fat content with $\mathrm{n}$-hexane for better defatting and the defatted portion was separated through filtration. Then it was dried overnight in oven at $50^{\circ} \mathrm{C}$ Finally it was milled to a powder form and then sieved through 250 $\mu \mathrm{m}$ sieves to remove all fibers and it was stored at $4^{\circ} \mathrm{C}$ for further analysis [11].

\subsection{Proteins Hydrolysis}

Defatted lung and bone protein was dissolved with distilled water by adjusting the $\mathrm{pH}$ to 7.5 using $1 \mathrm{~N} \mathrm{NaOH}$ or $1 \mathrm{~N} \mathrm{HCl}$, mixed the enzyme and incubated at $55^{\circ} \mathrm{C}$ for $3 \mathrm{hr}$.

Followed to protein isolation (section 7.2.) soya bean hydrolysis is done by the same process to offal hydrolysis. Then, after $3 \mathrm{hr}$ of incubation the inactivation of the enzyme took place by boiling the solution for $5 \mathrm{~min}$. Finally, the hydrolysate solution was dried at $40^{\circ} \mathrm{C}$ overnight in oven. After drying, the hydrolysate was mashed until it became powder and sieved through $250 \mu \mathrm{m}$ sieves to use as a peptone for microbiological media.

\section{Test of Protein Hydrolysate as Microbiological Media Components}

\subsection{Media Preparation}

Microbial media were prepared from the hydrolysate of defatted flour of soya bean, lung, bone and commercial peptone agar that has a composition of $(0.5 \%$ peptone, $0.1 \%$ dextrose, $0.1 \%$ yeast extract and $1 \%$ agar) in distilled water. The $\mathrm{pH}$ was adjusted to $7.4 \pm 0.2$ at $25^{\circ} \mathrm{C}$ by $1 \mathrm{~N} \mathrm{NaOH}$. Finally the media were sterilized by autoclaving at $121^{\circ} \mathrm{C}$ for $15 \mathrm{~min}$ [12]. From each culture broth dilution, $0.1 \mathrm{ml}$ was spread on the agar medium. The plates were incubated at $37^{\circ} \mathrm{C}$ for $24-48 \mathrm{hr}$. For each culture duplicate plates were prepared [11].

\subsection{Inoculum Preparation}

From Ethiopian health and nutrition research institution (EHNRI) a pathogenic bacteria of E. coli, Streptococcus agalaetiae, Staphylococcus aureus, Shigella flexneri, Salmonella thyphimerium and Klebsiella pneumonia were obtained. Each bacterium was separately cultured on nutrient agar for $24 \mathrm{hr}$ at $37^{\circ} \mathrm{C}$ to refresh the pathogens and for isolation of pure colony. Single colony was taken and inoculated to nutrient broth and incubated for $24 \mathrm{hr}$. Then 1 $\mathrm{ml}$ of cultured broth was serially diluted in sterile distilled 
water $\left(10^{4}-10^{9}\right.$ dilution) [11].

\subsection{Growth Measurement}

The numbers of colonies were directly counted from the culture. It was done in duplicate to increase the validity of number of colony counting.

\section{Results}

\subsection{Isolation and Screening of Protease Producing Bacteria}

Based on the formation of a clear zone around the colony on skim milk agar media (Figure 1) a total of 17 bacterial isolates were selected as protease producers.

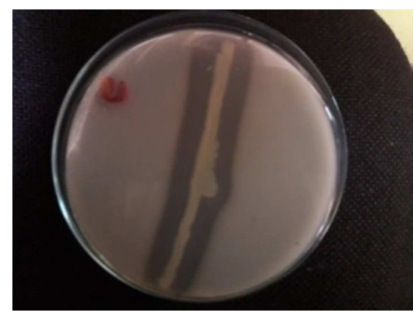

Figure 1. Protease producing isolates on skim milk agar media.

On the basis of enzyme production in liquid culture and their ability to grow in SSF, 4 isolates were selected for further screening. Out of the four isolates, one isolate that has relatively high enzyme production designated as $a a u_{5}$, was selected for further study.

\subsection{Characterization of Selected Isolate}

Isolate $\mathrm{aau}_{5}$ was a Gram-negative, rod shaped, catalase positive, and white creamy with irregular shape of colonies on skim milk agar medium (Table 1). This isolate was not able to hydrolyze starch and gelatin but can hydrolyze skim milk. Based on these morphological and biochemical features this isolate was tentatively grouped under the genus Pseudomonas.

Table 1. Morphological and biochemical features of the bacterial isolate $\left(a^{a} u_{5}\right)$.

\begin{tabular}{lll}
\hline No. & Characterization & Result \\
\hline 1 & Shape & Rod \\
2 & Gram staining & $-\mathrm{ve}$ \\
3 & Catalase & $+\mathrm{ve}$ \\
4 & Casein hydrolysis & $+\mathrm{ve}$ \\
5 & Starch hydrolysis & $-\mathrm{ve}$ \\
6 & Gelatin hydrolysis & $-\mathrm{ve}$ \\
7 & Skim milk hydrolysis & $+\mathrm{ve}$ \\
\hline
\end{tabular}

\subsection{Enzyme Production Through Solid State Fermentation}

\subsubsection{Effect of Moisture Level on Protease Production}

To determine the optimum moisture level for enzyme production isolate $\mathrm{aau}_{5}$ was grown on wheat bran containing different moisture levels. Maximum enzyme production $(5,031.93 \mathrm{U} / \mathrm{g})$ was observed at moisture level of $66.7 \%$. With increasing moisture level above its optimum enzyme production sharply decreased (Figure 2).

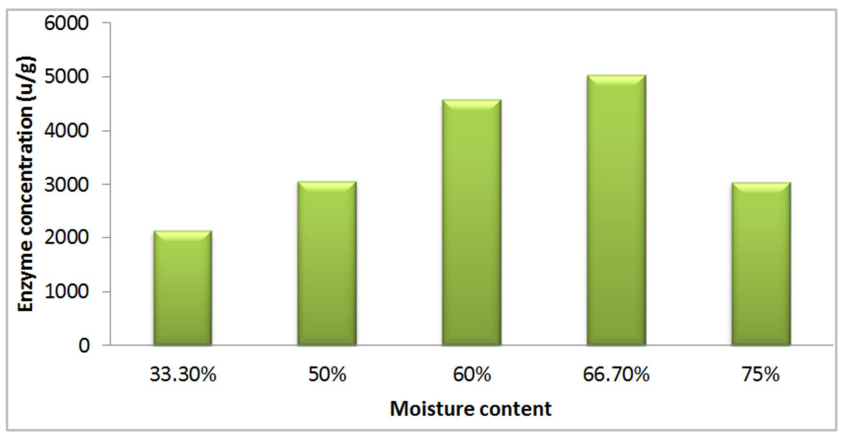

Figure 2. Moisture levels of SSF medium and enzyme production by isolate $a a u_{5}$.

\subsubsection{Effect of Incubation Period on Protease Production}

Enzyme production increased as time of incubation increased from $24 \mathrm{hr}-72 \mathrm{hr}$ (Figure 3) in the solid state fermentation. Then maximum protease production $(5773 \mathrm{U} / \mathrm{g})$ of $a a u_{5}$ was observed at $72 \mathrm{hr}$ of incubation. After $72 \mathrm{hr}$ of incubation period a gradual reduction in the relative enzyme production was observed.

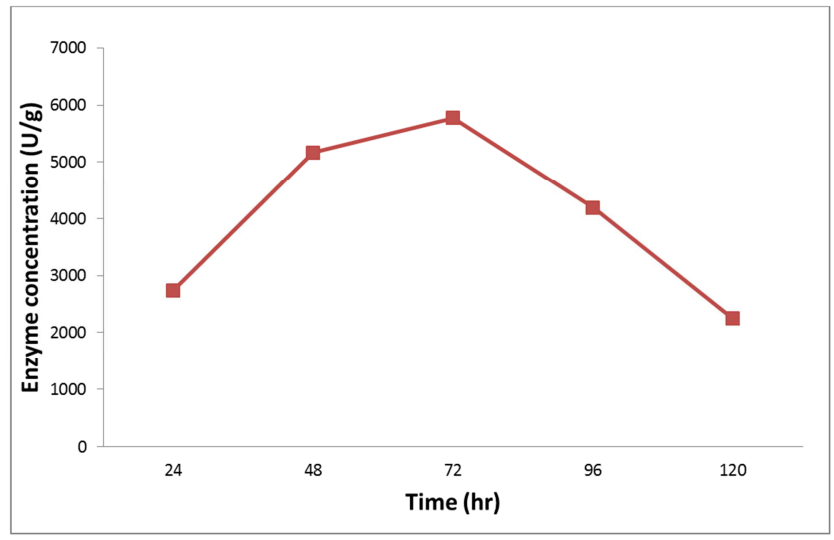

Figure 3. Time course of protease production by isolate aau . $_{\text {. }}$

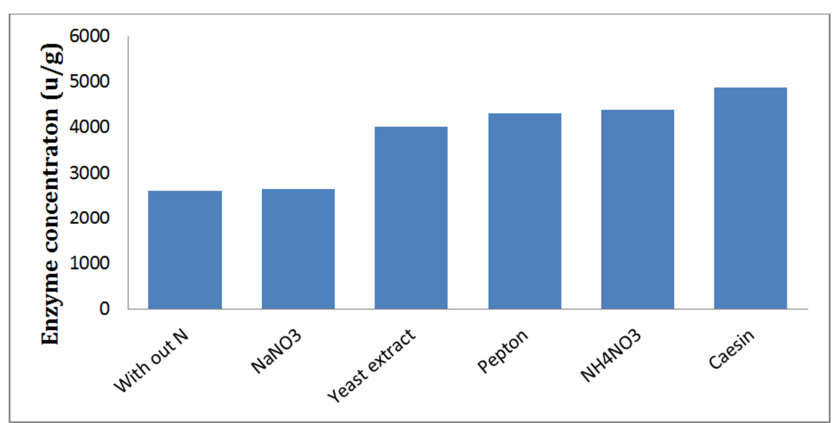

Figure 4. Effects of different nitrogen sources on protease production by isolate aau $_{5}$.

\subsubsection{Effect of Nitrogen Source on Enzyme Production by $\boldsymbol{a a u}_{5}$}

Best nitrogen source was determined in the presence and absence of different nitrogen source under a solid state fermentation in a wheat bran medium. Of the different 
nitrogen supplements tested enzyme production was the highest $(4870 \mathrm{U} / \mathrm{g})$ in the presence of casein. On the other hand, using Sodium nitrate for $a a u_{5}$ growth showed almost equal amount of protease compared to protease production in the absence of nitrogen supplement (Figure 4). Relatively, addition of organic nitrogen source (yeast extract, peptone and casein) supported higher enzyme production.

\subsection{Characteristics of the Protease Enzyme}

\subsubsection{Effect of $\mathrm{pH}$ on the Activity of $\mathrm{aau}_{5}$ Protease}

The $a^{a} u_{5}$ protease has higher activity in wider $\mathrm{pH}$ range and the maximum activity was observed at $\mathrm{pH}$ 7.5. The enzyme maintained more than $75 \%$ of its activity in the $\mathrm{pH}$ range of 6 to 10. Relatively, the lowest activity was observed at $\mathrm{pH} 10.5$ (Figure 5).

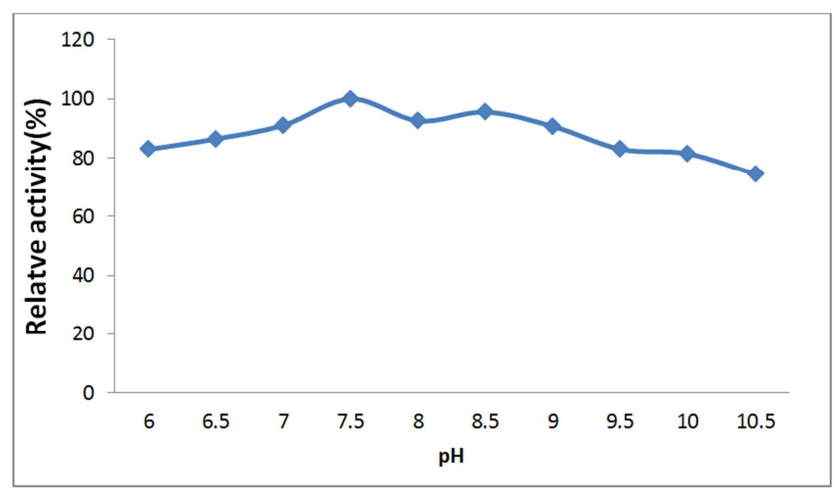

Figure 5. Relative activity of aau 5 protease at different $\mathrm{pH}$ value.

\subsubsection{Effect of Temperature on the Activity of Protease}

The optimum temperature for $a a u_{5}$ protease was at $55^{\circ} \mathrm{C}$ and retained $90 \%$ of its maximum activity at $60^{\circ} \mathrm{C}$ (Figure 6).

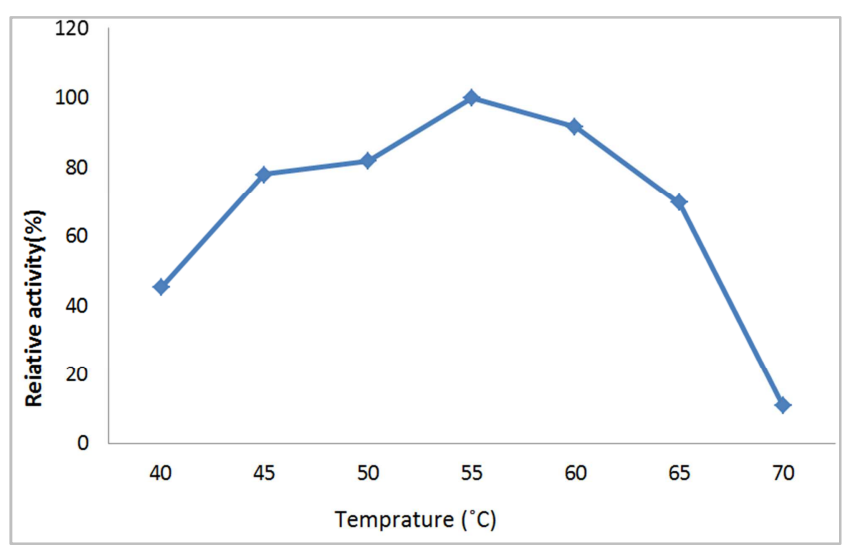

Figure 6. The relative activity of aau 5 protease at different temperature values.

\subsubsection{Effect of Temperature on the Stability of Protease}

The temperature stability of $a a u_{5}$ protease was determined by assaying the pre-incubated enzyme. The relative activity of this enzyme decreased with increasing incubation temperature. At $55^{\circ} \mathrm{C}$ about $41 \%$ of its activity was retained after $60 \mathrm{~min}$. The enzyme also retained $60 \%$ of its activity after $1 \mathrm{hr}$ incubation at $50^{\circ} \mathrm{C}$ (Figure 7).

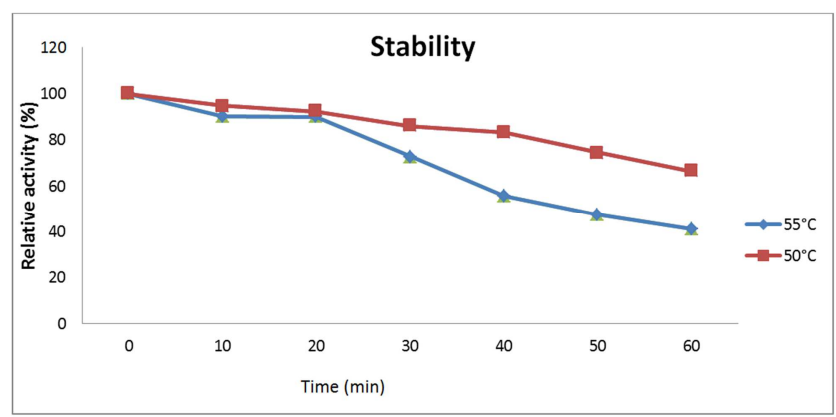

Figure 7. Temperature stability of aau $u_{5}$ protease at $50^{\circ} \mathrm{C}$ and $55^{\circ} \mathrm{C}$.

\subsection{Test the Hydrolysate for Bacterial Growth as a Microbiological Media on the Laboratory Produced Peptone}

The peptone produced from lung and bone was compared with the soya bean and commercial peptone as a microbial media for the growth of different pathogenic microorganisms. Media prepared from laboratory prepared peptone supported a good growth of the test bacteria and was better than media prepared from commercial peptone (Table 2).

Compared to the commercial peptone agar, E.coli and Klebsiella pneumonia showed better growth in media prepared from lung, bone, and soya peptone (Figure 8). LPA and BPA were better for microbial growth in almost all organisms except Klebsiella pneumoniae which was slightly higher CFU in commercial peptone agar than BPA and SPA. Relatively, Staphylococcus aureus showed the least growth in all media. In general the peptone from animal source (lung and bone) was better for bacterial growth than soya bean and commercial peptone agar media.

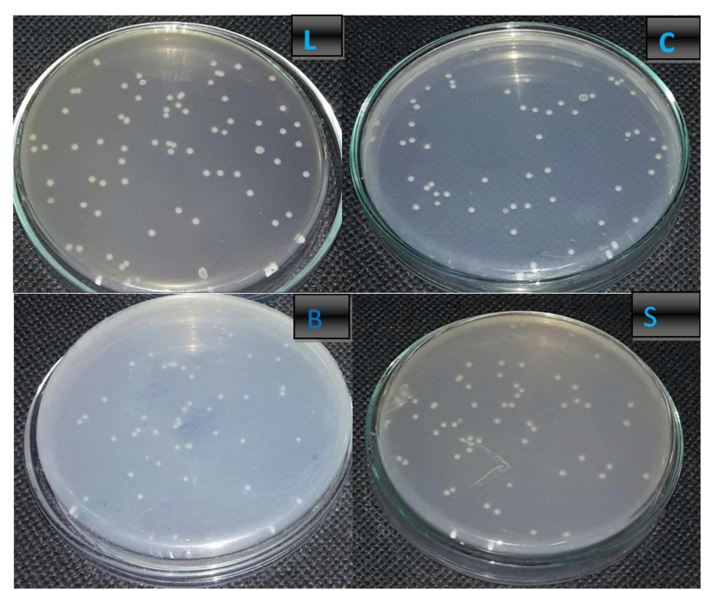

Note: - B, BPA; C, CPA; L, LPA and S, SPA

Figure 8. Colony of Salmonella agalaetiae on lung peptone agar (LPA), bone peptone agar (BPA), soya peptone agar (SPA) and commercial peptone $\operatorname{agar}(C P A)$ 
Table 2. Comparison of pathogenic bacterial colony count on lung and bone peptone agar against soya bean and commercial peptone agar.

\begin{tabular}{|c|c|c|c|c|}
\hline \multirow{2}{*}{ Test Bactria } & \multicolumn{4}{|l|}{$C f u / m l$} \\
\hline & LPA & BPA & SPA & CPA \\
\hline E.coli & $87 \times 10^{7}$ & $89 \times 10^{7}$ & $80.14 \times 10^{7}$ & $70.28 \times 10^{7}$ \\
\hline Shigella flexneri & $37.14 \times 10^{7}$ & $42.14 \times 10^{7}$ & $29.57 \times 10^{7}$ & $32.21 \times 10^{7}$ \\
\hline Streptococcus agalactiae & $11.14 \times 10^{7}$ & $13.43 \times 10^{7}$ & $7.57 \times 10^{7}$ & $7.86 \times 10^{7}$ \\
\hline Staphylococcus aureus & $4.36 \times 10^{7}$ & $6.21 \times 10^{7}$ & $0.29 \times 10^{7}$ & $1.07 \times 10^{7}$ \\
\hline Salmonella thyphimerium & $22.21 \times 10^{7}$ & $20.71 \times 10^{7}$ & $21.14 \times 10^{7}$ & $13.57 \times 10^{7}$ \\
\hline Klebsiella pneumoniae & $42.57 \times 10^{7}$ & $39.35 \times 10^{7}$ & $40.21 \times 10^{7}$ & $41.21 \times 10^{7}$ \\
\hline
\end{tabular}

Note: - BPA, bone peptone agar; CPA, Commercial peptone agar; LPA, lung peptone agar and SPA, soya bean peptone agar.

\section{Discussion}

Soil contains many nutrients and it is often considered as a major source of different useful microbes, including those producing proteases [13]. In this study the $75 \%$ of the bacterial isolates were shown a proteolysis activity on skim milk agar and they were isolated from soil sample. For the initial isolation of protease producers a simple and efficient screening procedure could have huge advantages. Based on its simplicity, rapidity, range of detection and sensitivity, the clear zone formation due to proteolytic activity of the microbe on the skim milk agar plate was used for the initial screening of protease producing microbes [14]. However, in this study the size of clear zone on skim milk agar was given ambiguous result in some selected isolate. Therefore, use of other screening method like enzyme production on SMF and SSF was necessary to select best protease producing isolate.

The selected isolate (isolate $a a u_{5}$ ) grow under SSF using wheat bran shows its potential as a source of commercially important enzyme with low production cost. For the largescale application of proteases reduction in the production cost of the enzyme (s) is very important. Currently large-scale production of proteases in developed countries is carried out in submerged fermentation. However, in developing countries enzyme production through solid state fermentation (SSF) offer several advantages. First, it uses cheap agro processing wastes that can help to greatly reduce the production cost. Secondly, growth under SSF is often associated with higher product yield [15]. Third, most of bacteria require higher water activity for growth, but SSF has a lower risk of contamination.

The growth and enzyme production of microorganisms under a SSF can be influenced by the moisture level [16]. The highest enzyme production for isolate $a a u_{5}$ (reaching up to $5031 \mathrm{U} / \mathrm{g}$ ) was observed in the presence of $66.7 \%$ moisture. Increasing the moisture content to $75 \%$ resulted in reduction of enzyme production by more than $40 \%$. Similarly, enzyme production below the optimum moisture level was also lower. Most bacterial species optimally grow in the presence of high water activity. But in SSF increasing moisture content above a critical value could affect porosity of the medium and limit gas transfer [17]. On the other hand low moisture content leads to reduction in nutrient diffusion and that can also affect the enzyme production [15]. The optimum moisture content required for high enzyme production is different based on the strains. For example maximum protease enzyme production by Penicillium sp. was observed at moisture content of $50 \%$ [18].

In most organisms, maximum extracellular enzyme production is often observed at or around the end of the exponential or beginning of the stationary phase where the concentration of one or more nutrients in the medium is depleted [19]. Isolate $a a u_{5}$ showed a fast enzyme production on wheat bran under SSF (up to $2,740 \mathrm{U} / \mathrm{g}$ ) after $24 \mathrm{hr}$ of incubation. But, maximum enzyme production was observed after $72 \mathrm{hr}$ incubation. After that enzyme production showed a sharp decrease. The end of the stationary phase of microbial growth cycle is associated with depletion of essential nutrients in the culture medium and accumulation of waste product in the medium that inhibit growth and enzyme production [20].

For maximum enzyme production the culture medium must contain the required carbon and nitrogen sources. For organisms that grow under SSF using wheat bran, the solid substrate could supply up to $75 \%$ of the required carbohydrate [21]. This shows that there is no need to supplement wheat bran with additional carbon sources. On the other hand the nitrogen content of wheat bran may not be sufficient to support microbial growth. Therefore, there is a need to add nitrogen supplements to bring about optimal growth under SSF. For isolate $a a u_{5}$ protease enzyme production under SSF was higher in cultures supplemented with organic nitrogen than cultures grown without any nitrogen supplement and cultures supplemented with $\mathrm{NaNO}_{3}$ as inorganic nitrogen source. Other reports also showed that supplementing wheat bran with organic nitrogen sources lead to better growth and protease production [22]. This shows wheat bran may not contain the required amount of nitrogen for the optimum growth of the organism. Some reports showed that supplementation of some strains with inorganic nitrogen source resulted in better growth and protease production [23]. This shows the requirement of specific nitrogen source differs from organism to organism [24].

Protease $a a u_{5}$ was active in the $\mathrm{pH}$ range of 6.5-9.0, with an optimum at $\mathrm{pH}$ 7.5. Protease optimally active around neutrality are considered ideal for application in foods processing industries [25]. Moreover, for industrial application in food processing proteases active in the temperature range of $50-60^{\circ} \mathrm{C}$ are considered ideal [26]. $a a u_{5}$ protease showed very good stability and activity in the temperature range of $50^{\circ} \mathrm{C}$ to $55^{\circ} \mathrm{C}$. This shows that the enzyme has a good potential for application in the protein hydrolysis and other food processing industries. 
Hydrolysis by protease $a a u_{5}$ was used for the production of peptone from slaughter house offal (lung and meat extracted from bone) and soybean protein used for the formulation of microbiological growth media. [27] Reported that peptone prepared from different sources show significant differences in supporting good microbial growth. In this study, compared to the commercial peptone, peptone produced in the laboratory from slaughterhouse offal (lung and bone) and from soybean protein supported better growth of the test bacterial species (Table 2). The difference in the different peptone preparations might be a result of differences in composition of essential amino acids, vitamins, and/or other growth factors [28]. To date media used for microbial growth in Ethiopia is imported from abroad. Given the large quantity of offal released each day in the country, the results of this study suggest the existence of a good potential to produce effective microbiological media from cheap local resources and help the country save in foreign currency.

In this study the growth of tested bacteria favorably well grow in animal source compared to that of plant and commercial source of peptone. Based on the source and hydrolysis process of proteins, the essential amino acids in the peptone are also different. For example the amino acids composition of plant and animal proteins is quite different [29]. In addition to that peptones that are produced from plants source have an antibacterial property over that of animal based peptone. Soya bean is one of the plant sources of protein that have an anti-microbial effect against Staphylococcus aureus [30].

Peptones derived from animal source have also an advantage by reducing the cost of raw material for peptone production. According to Durrani et al.'s study, most peptone from plant source is derived from edible source of cereal and leguminous plants like soya bean [31]. In contrast, peptone from slaughterhouse offal can be produced from inedible parts such as lung, tendons, intestine and bone allowing waste valorization. And these ultimately greatly reduce the production cost of the peptone while at the same time avoiding environmental pollution from the release of offal.

\section{Conclusion and Recommendation}

Protein hydrolysates prepared from slaughterhouse offal through enzymatic hydrolysis were tested as potential microbiological media. Peptone prepared in the lab supported the growth of different test microorganisms better than or equal to commercial peptone. Given the large number of animals slaughtered each year in Ethiopia and the amount of offal disposed as waste, protein recovery and enzymatic hydrolysis could lead to production of protein hydrolysates with huge economic benefit. This requires availability of efficient enzymes with affordable cost. The result of this study shows the potential of Ethiopia's bacterial diversity as a source of new enzymes for protein hydrolysis. The fact that the organism grew under SSF fermentation using cheap agricultural waste help to greatly reduces the cost of enzyme production.

For large-scale application it is recommended that enzyme production and hydrolysis reaction is scaled up. It is also recommended that the resulting protein hydrolysate to be tested or used in the food, animal feed, and cosmetics industries is studied.

\section{References}

[1] Gupta, A., Roy, I., Patel, R. K., Singh, S. P., Khare, S. K. and Gupta, M. N. (2005). One-step purification and characterization of an alkaline protease from haloalkaliphilic Bacillus sp. Journal of chromatography. pp. 1075 (1): 103108.

[2] Harmsen, M. M. and De Haard, H. J. (2007). Properties, production, and applications of camelid single-domain antibody fragments. Applied microbiology and biotechnology. pp. 77 (1): 13-22.

[3] Puri, S., Beg, Q. K. and Gupta, R. (2002). Optimization of alkaline protease production from Bacillus sp. by response surface methodology. Current microbiology. pp. 44 (4): 286290.

[4] Radha, S., Nithya, V. J., Himakiran Babu, R., Sridevi, A., Prasad, N. and Narasimha, G. (2011). Production and optimization of acid protease by Aspergillus spp under submerged fermentation. Arch Appl Sci Res. pp. 3 (2): 155-63.

[5] Dalev, P. G. (1994). Utilisation of waste feathers from poultry slaughter for production of a protein concentrate. Bioresource Technology. pp. 48 (3): 265-267.

[6] Oliva-Teles, A., Cerqueira, A. L. and Gonçalves, P. (1999). The utilization of diets containing high levels of fish protein hydrolysate by turbot (Scophthalmus maximus) juveniles. Aquaculture. pp. 179 (1): 195-201.

[7] Rebah, F. B. and Miled, N. (2013). Fish processing wastes for microbial enzyme production: a review. 3 Biotech. pp. 3 (4): 255-265.

[8] Irshad, A. and Sharma, B. D. (2015). Abattoir by-product utilization for sustainable meat industry: a review. Journal of Animal Production Advances. pp. 5 (6): 681-696.

[9] Nolsoe, H. and Undeland, I. (2009). The acid and alkaline solubilization process for the isolation of muscle proteins: state of the art. Food and Bioprocess Technology. pp. 2 (1): 127.

[10] Bogracheva, T. Y., Bespalova, N. Y. and Leont'ev, A. L. (1996). Isolation of $11 \mathrm{~S}$ and $7 \mathrm{~S}$ globulins from seeds of glycine max. Applied Biochemistry and Microbiology. pp. 32 (4): 429-433.

[11] Andualem, B. and Gessesse, A. (2013). Production of microbial medium from defatted brebra (Milletia ferruginea) seed flour to substitute commercial peptone agar. Asian Pacific journal of tropical biomedicine. pp. 3 (10): 790-797.

[12] Uzeh, R. E., Akinola, S. O. and Olatope, S. O. A. (2006). Production of peptone from soya beans (Glycine max L merr) and African locust beans (Parkia biglobosa). African Journal of Biotechnology. pp. 5 (18): 1684-1686. 
[13] Alves, P. D. D., de Faria Siqueira, F., Facchin, S., Horta, C. C. R., Victória, J. M. N. and Kalapothakis, E. (2014). Survey of microbial enzymes in soil, water, and plant microenvironments. The open microbiology journal. pp. 8 (25): $25-31$.

[14] Rajamani, S. and Hilda, A. (1987). Plate assay to screen fungi for proteolytic activity. Current Science. pp. 56 (22): 11791181.

[15] Pandey, A. (2003). Solid-state fermentation. Biochemical Engineering Journal. pp. 13 (2): 81-84.

[16] Kim, J. H., Hosobuchi, M., Kishimoto, M., Seki, T., Yoshida, T., Taguchi, H. and Ryu, D. D. (1985). Cellulase production by a solid state culture system. Biotechnology and Bioengineering. pp. 27 (10): 1445-1450.

[17] Lonsane, B. K., Saucedo-Castaneda, G., Raimbault, M., Roussos, S., Viniegra-Gonzalez, G., Ghildyal, N. P., Ramakrishna, M. and Krishnaiah, M. M. (1992). Scale-up strategies for solid state fermentation systems. Process Biochemistry. pp. 27 (5): 259-273.

[18] Agrawal, D., Patidar, P., Banerjee, T. and Patil, S. (2004). Production of alkaline protease by Penicillium sp. under SSF conditions and its application to soy protein hydrolysis. Process biochemistry. pp. 39 (8): 977-981.

[19] Gupta, R., Beg, Q. and Lorenz, P. (2002). Bacterial alkaline proteases: molecular approaches and industrial applications. Applied microbiology and biotechnology. pp. 59 (1): 15-32.

[20] Maier, R. M. and Soberon-Chavez, G. (2000). Pseudomonas aeruginosa rhamnolipids: biosynthesis and potential applications. Applied microbiology and biotechnology. pp. 54 (5): 625-633.

[21] Shewry, P. R., Hawkesford, M. J., Piironen, V., Lampi, A. M., Gebruers, K., Boros, D., Andersson, A. A., Åman, P., Rakszegi, M., Bedo, Z. and Ward, J. L. (2013). Natural variation in grain composition of wheat and related cereals. Journal of agricultural and food chemistry. pp. 61 (35): 8295-8303.

[22] Phadatare, S. U., Deshpande, V. V. and Srinivasan, M. C. (1993). High activity alkaline protease from Conidiobolus coronatus (NCL 86.8. 20): enzyme production and compatibility with commercial detergents. Enzyme and microbial technology. pp. 15 (1): 72-76.

[23] El-Safey, E. M. and Abdul-Raouf, U. M. (2004). Production, purification and characterization of protease enzyme from Bacillus subtilis. In International Conferences for Development and the Environment in the Arab World, Assiut University. pp. 2 (4): 23-25.

[24] Kumar, C. G., Tiwari, M. P. and Jany, K. D. (1999). Novel alkaline serine proteases from alkalophilic Bacillus spp.: purification and some properties. Process Biochemistry. pp. 34 (5): 441-449.

[25] Rao, M. B., Tanksale, A. M., Ghatge, M. S. and Deshpande, V. V. (1998). Molecular and biotechnological aspects of microbial proteases. Microbiology and molecular biology reviews. pp. 62 (3): 597-635.

[26] Racheal, O. O., Ahmed, A. T. F., Ndigwe, E. V. and Morakinyo, S. D. (2015). Extraction, purification and characterization of protease from Aspergillus Niger isolated from yam peels. International Journal of Nutrition and Food Sciences. pp. 4 (2): 125-131.

[27] Gray, V. L., Müller, C. T., Watkins, I. D. and Lloyd, D. (2008). Peptones from diverse sources: pivotal determinants of bacterial growth dynamics. Journal of applied microbiology. pp. 104 (2): 554-565.

[28] Dufosse, L., De La Broisse, D. and Guerard, F. (1997). Fish protein hydrolysates as nitrogen sources for microbial growth and metabolite production. Recent Res. Dev. Microbiol.pp. 1: 365-381.

[29] Nehete, J. Y., Bhambar, R. S., Narkhede, M. R. and Gawali, S. R. (2013). Natural proteins: Sources, isolation, characterization and applications. Pharmacognosy reviews. pp. 7 (14): 107-116.

[30] Wang, Q., Wang, H. and Xie, M. (2010). Antibacterial mechanism of soybean isoflavone on Staphylococcus aureus. Archives of microbiology. pp. 192 (11): 893-898.

[31] Durrani, A., Ali, A., Durrani, S., Shaikh, J. B., Upadhyay, A. and Khan, Z. H. (2011). Non-animal peptone for serum free cultivation of recombinant mammalian and animal cells. International Journal of Biology. pp. 3 (1): 140-145. 